\title{
THEOLOGY AND THE PUBLIC SQUARE: MAPPING THE FIELD
}

\section{Elaine Graham}

\begin{abstract}
This article asks what happens when theology 'goes public': what some of the key issues are in relation to the changing profile and role of religion in society - global, local and national and how theologians have approached the issue of how the voices of faith might speak into the public domain. Where are the critical points in society, economics, politics, health and welfare where we feel the voices and influence of people of faith are most effective; and where are they absent; or most needed? What moves us to hope and action in relation to our 'Common Life'?
\end{abstract}

\section{Keywords}

PUBLIC THEOLOGY, GRENFELL TOWER, COMMON GOOD, SOCIAL CAPITAL, RELIGIOUS CAPITAL, SPIRITUAL CAPITAL.

\section{Introduction}

It is often said that 'Religion and politics don't mix'. Religion is assumed to be a matter of private faith, a matter of feeling, care and subjective belief. Church leaders who have the temerity to comment on public affairs are advised by politicians to 'stop interfering' in matters of State and stick to their proper domain, namely personal morality. Yet this division itself has a history; it is a legacy of Western modernity, which established a demarcation between 'public' and 'private' spheres - a distinction that was also gendered. 
The public arena was associated with reason, governance, the State, and was identified as a predominantly male world. The private domain belonged to women, and was the realm of domesticity, emotion, feeling, care and family (Lloyd, 1984).

Historically speaking, however, religion has always been tied into structures of state and government. Doctrines such as the Divine Right of Kings provided theological justification for temporal rule. Similarly, right up to the twentieth century in Europe, religious groups have been engaged in the provision of education and welfare services; religious teachings have provided the basis of legal systems; and religious allegiance itself has often been regarded as a question of political loyalty (Kim, 2011) (Strenski, 2010). Politically, too, religious groups have been important places of formation, resistance, preparation for wider political and civil engagement: think of the connections between Methodism and trade unions, churches and civil rights in the United States, anti-slavery campaigns, campaigns such as church-led Jubilee 2000 around international development.

Yet despite all this evidence, and a legacy of faith-based public engagement, we still inherit these slightly contradictory assumptions: it is assumed that religion is not a public matter, and yet we cannot restrict the influence and potential of faith for public life. Perhaps this is in part a legacy of the debates in the second half of the twentieth century, often known as the secularisation thesis, which assumed that religion would disappear to the margins of public life. There were a number of dimensions to this trajectory of religious decline: firstly, religion was held to be diminishing in significance and influence as a cultural habit and universal reference point for language, morality, symbols of unity. Secondly, it was losing its capacity as a political or civic force, either in terms of mobilising citizens or 
shaping public opinion. Thirdly, it was withdrawing to the margins of civil society, not least because in Western countries from the mid-twentieth century, the Welfare State took over many of the voluntary and charitable functions of churches and other religious groups (Bruce, 2002; Woodhead and Catto, 2012).

By the beginning of the twenty-first century, however, the secularisation thesis began to prove less plausible in the light of a number of social, political and cultural developments. While many of the features of the trajectory of religious decline, typical of Western modernity, are still apparent, there are compelling and vibrant signs of religious activism, not least in public life and politics: local, national and global. For example, in Western democracies such as the UK, faith-based organizations are experiencing a heightened public prominence as partners with government in the delivery of welfare and other public services (Dinham, 2012). Religion continues to be a potent force in many aspects of global civil society and is increasingly cited by governments as a significant source of social capital and political mobilization. Similarly, while patterns of religious observance and affiliation may be declining at an accelerating rate (National Centre for Social Research, 2019), other indicators are shifting and mutating. Interest in personal spirituality beyond creedal and institutional expressions of religion continues to be strong (ComRes, 2013, Pew Forum, 2010) not least in the way concepts of spiritual health and spiritual care are increasingly part of institutional provision and professional practice (Lynch, 2007; White 2006; Zsolnai and Flanagan, 2019).

Within human rights legislation, the inclusion of categories of 'religion and belief' alongside markers of identity such as 'race' and ethnicity, gender, sexuality and dis/ability 
has given rise to a number of high-profile cases across Europe in which persons of faith have challenged the neutrality of the public square by insisting on special treatment, such as the wearing of particular religious clothing or symbols, or demands for particular dispensations of practice and conscience (Kettell, 2015). These have proved quite contentious, however, since such cases represent a potential conflict between respect for freedom of belief (around religion) and recognition of universal human rights and liberties (around gender, disability, sexuality or race and ethnicity).

Another determining factor has been that of globalisation. Global migration has fostered religious diversity and heightened awareness of the links between religious profession and cultural or ethnic identity (Hjelm, 2015; Pew Forum on Religion \& Public Life, 2012). So religion (and God) is back; although there is still resistance to 'doing God' in public and scepticism towards religion as a form of public reason or credible source of debate (Bullivant, 2017; Harris, 2005; Woodhead, 2014).

These particular challenges - of a greater prominence for religion combined with enduring scepticism even hostility to doing God in public - suggests that if the Christian churches are committed to any kind of significant public role, the nature of public theological discourse must become more nuanced, more circumspect; possibly, even, more 'apologetic' (in the sense of being prepared to justify the presence of religious actors and voices in the public square) (Graham, 2017) .

Institutions such as the churches, then, are no longer speaking into a common frame of reference, in which their 'theological and moral allusions fall comfortably on waiting ears' 
(Graham, 2013, p. xx). Religious voices today have no automatic or authoritative right to speak, given the nature of the secular, pluralist, public realm. They now find themselves in the kind of position that prompts Marion Maddox to ask, 'What legitimacy can a theologically-based contribution claim where Christianity commands no automatic attention?' (2007, p. 82) Public theology speaks into an increasingly contested and fragmented context, and is divided as to the nature of its address to the world. With what voice, from what sources, might the Church speak? How authoritative and binding are its own traditions and practices, and how far does that need to accommodate to a wider audience?

\section{The Scope of Public Theology}

The emerging discipline of 'Public Theology' has been exercised by these questions in recent years, and in particular the question of how it speaks with the voice of faith into an increasingly fragmented and sceptical world (Graham, 2013; Hogue, 2010; Pearson, 2007; Spencer, 2017). Public Theology, essentially, asks what the relationship between religion and secular society or public life might be and how these two spheres might speak to one another, despite that conventional assumption that there is little or no relevance or purchase between them (Bedford-Strohm, 2007; de Gruchy, 2007; Kim, 2011).

The actual process of theological engagement with public issues begins with basic questions of definition in relation to the scope of the term 'public.' Our distinction probably dates from the beginnings of modernity, where, according to the German philosopher Jürgen Habermas, the distinction between public and private depends on the creation of a 
specific sphere of activity, the 'life-world', free of colonization by the market or the state (Habermas, 1989). However, new technologies may be promulgating a new revolution. So, for example, the advent of social media may lead us to feel as if our selves are turned inside out and the conventional boundaries we use to protect our private selves are dissolving. What we might consider most private and personal is tweeted away; and even data about ourselves, our health, our finances, our shopping habits and so on can be 'harvested' by business and government. Is it an issue of theological significance to wonder about where the boundaries and limits of privacy and the integrity of our own life world might lie? (Stoddart, 2011)

One key premise within public theology is that there is no single 'public'; no single way in which the voices and values of faith might be mediated into the public square; and no single way in which 'public theology' might express itself. We can think of public theology as the study of the public relevance of religious thought and practice, normally within Christian tradition. It is both academic discipline and ecclesial discourse, in that it seeks to comment and critically reflect from a theological perspective on aspects of public life such as economics, politics, culture and media (Breitenberg, 2010; Graham and Lowe, 2009; Smit, 2007a; Smit, 2007b).

When public theologians talk about the 'public' it is not synonymous with party politics or simple matters of government. Rather, as Max Stackhouse put it, 'the public is prior to the republic', since 'the moral and spiritual fabric of civil society is and should be more determinative of politics than politics is for society and religion' (Stackhouse, 2007a, p. 101; see also Tippett 2004). Public theology is more comprehensive than political theology, 
since the well-being of societies rests on more than matters of State and encompasses the economy, legal systems, voluntary and charitable activity, media and other aspects of public policy.

If political theology is concerned with political processes and institutions and the relationship between models of temporal authority and divine rule, public theology seeks to interpret the moral, metaphysical and theological dimensions of a society's economic, cultural and intellectual milieu. In that respect, it is concerned with the material realities of social institutions and a sphere of normative ideals, constituted by informed public opinion, characterized by freedom of speech and expression; a 'specifically discursive sphere of interchange in civil society ... the sort of deliberation in common that shapes a responsible citizenry' (Tanner 1996, p. 80).

\section{Holiness, Justice, Truth, Creativity}

In considering the scope of the 'public' itself, an influential voice has been the American Roman Catholic theologian David Tracy, who identified the task of Christian theology as addressing three distinct constituencies, or 'publics': Church, society and the academy. Writing in 1981 about the 'social portrait of the theologian' he argued that all theology emerges from a number of contexts to which the theologian is accountable. The pluralism of modern society requires anyone, including the theologian, to take into account a variety of perspectives and sources on the nature of human understanding, what makes a good society, how people will make moral decisions and so on (Tracy, 1981). 
Like David Tracy, the Reformed theologian Max Stackhouse insists on the 'public-ity' of theology. In a pluralist (and increasingly globalizing) culture, theology must address multiple publics. To Tracy's three publics, Stackhouse adds a fourth public, of economics and the market, and summarizes these four areas of public life as respectively concerned with 'holiness, justice, truth and creativity' (Stackhouse, 2006).

Conventionally, therefore, the notion of 'public' has carried a dual meaning for public theologians. Firstly, it focuses on the corporate, political and societal meanings of faith, in contrast to forms of religious belief and practice that confine faith to private and pietist intentions (Breitenberg 2003; Stackhouse 2007a). It aims to comment on and inform public issues and matters of concern from the perspective of faith.

Secondly, it reflects a commitment on the part of public theologians to conduct debates about the public trajectories of faith and practice in ways that are transparent and publicly accessible and defensible (Breitenberg 2003). It seeks to be transparent and accountable to a wider (secular) public about the grounds of its reasoning; bilingual in bringing together public affairs with wisdom of tradition. Public theology sees itself as rooted in religious traditions, but strongly in conversation with secular discourse and public institutions.

Public theology is thus theologically informed public discourse about public issues, addressed to the church, synagogue, mosque, temple or other religious body, as well as the larger public or publics, argued in ways that can be evaluated and judged by publicly available warrants and criteria. 
Public theologians thus seek to communicate, by means that are intelligible and assayable to all, how Christian beliefs and practices bear, both descriptively and prescriptively, on public life and the common good, and in so doing possibly persuade and move to action both Christians and non-Christians. (Breitenberg 2003, p. 66)

Because of this emphasis on bilingualism or 'public-ity' it would be a fallacy to assume that theology is 'solely a self-expression of the church's own self-understanding' (Tracy 1984, p. 230). Theology, as talk about God, endeavours to speak about the whole of reality - even when these different publics are difficult to reconcile - because it is asking profound and enduring questions about all aspects of our lives together.

The work of the Lutheran minister and theologian Dietrich Bonhoeffer (1906-1945) serves as exemplary in this respect, not least for his enduring emphasis on the contextual, temporal and 'concrete' as the well-springs of theological reflection (Bonhoeffer, 1971). Influenced by the emergence of process theology, Bonhoeffer consistently resisted the kinds of dichotomies characteristic of Western modernity (expressed at the beginning of this article): sacred/secular, public/private, church/world, Christ/world. These, for him, were a denial of the doctrines of creation and incarnation; for him, true discipleship, the life of the Church, indeed Christ himself, can only be known in the concrete.

Bonhoeffer's radical incarnational orientation, therefore, speaks directly into contemporary public theologians' desire for accessible and effective intervention. Generally, public theology refers to the church genuinely engaging with those within and outside its institutions on issues of common interest and for the common good. 
Public theology, as I understand it, is not primarily and directly evangelical theology which addresses the Gospel to the world in the hope of repentance and conversion. Rather, it is theology which seeks the welfare of the city before protecting the interests of the Church ... (Forrester 2004, p. 6)

Similarly, as public theology considers issues confronting different communities, it soon becomes clear that we cannot afford the luxury of limiting our attention to one nation-state or culture. It is a phenomenon that is local, national and global. In engaging the challenges of immigration, climate change, human rights, human trafficking, health and epidemiology, poverty and hunger, or peace-building, for example, we need to widen our lens and our conversation.

Another feature of public theology is that it embodies both action and reflection. It may deliver a theological treatise on the environment or food poverty; but at the same time, somewhere else, people of faith are participating in demonstrations by Extinction Rebellion, or stacking tins in their local foodbank. Public theology has a 'performative' dimension, since actions may speak louder than words (Graham, 2017; Hogue, 2010; Spencer, 2017). Action challenges and informs theological understandings, even as theology tests the methods of activism.

\section{'Build Up Our Common Life'}


I would like to conclude this overview of public theology with two concepts that are central to its discussions about the aims and ends of its engagement with contemporary economics, politics and culture. Together, they remind us of the invocation within the Church's liturgy to 'build up our common life' as an essential vocation in relation to the public square. But in keeping with the strongly incarnational and worldly nature of public theology, this is a commonality defined not by ecclesiastical or creedal boundaries but by our shared humanity.

\section{The Common Good}

Firstly, the concept of the 'Common Good', often associated with Roman Catholic social thought, has been highly influential in helping churches think about the nature of its engagement in the public square (Hollenbach, 2006; Sagovsky and McGrail, 2015). As Anna Rowlands comments elsewhere in this issue, the tradition of the common good embodies the principles of interdependence, collective endeavour and the indivisibility of 'goods'. The well-being and flourishing of the whole is greater than any sectional self-interest. In the name of our common humanity, it is argued, the church should seek the good of all, and so its interventions in public debate and policy should not just be for its own advancement.

In an increasingly diverse and pluralistic world, however, does any notion of 'common' risk imposing a false unity or assume a consensus that actually excludes those with no voice or who are radically different from a supposed 'mainstream'? Should it, perhaps, be tempered by liberationist principles of the 'preferential option for the poor' such that any appeal to the common good might insist on the full participation of those with 
least power? (Ahern et al., 2016) What are the limits to our loyalty to a particular rendition of 'the common good' if that simply means attempting to rejuvenate a tired and broken political system? Given the political divisions in the UK over Brexit, to which Jonathan Draper's article alludes, it seems that at this moment, British society desperately needs people of good will whose calling is simply to safeguard the integrity of public life; to ensure that there are public spaces - physical, institutional and discursive - which are safe and 'civil' arenas in which important issues can be debated. ${ }^{1}$ Does the Church have sufficient 'social capital' and public trust to act in the name of political debate and association modelled on the traditionally 'liberal' values of equality, justice, respect and common purpose?

\section{Social, Religious and Spiritual Capital}

Secondly, the terminology of social, religious and spiritual capital has provided a further conceptual framework for public theologians to think about the constructive difference that religion can make. The terminology originates with the sociologist Robert Putnam, who considered the potential cost to Western society - in terms of public health, democratic participation and a diverse civil society - of the erosion of voluntary activity at the end of the twentieth century (Putnam, 2000). He coined the term 'social capital' to denote the extent to which social bonds and networks are maintained by a range of common activities, such as volunteering, local politics, membership of leisure societies and faith groups, and so forth.

\footnotetext{
${ }^{1}$ See, for example, proposals that the Archbishop of Canterbury might chair a People's Forum on Brexit: https://www.bbc.co.uk/news/uk-politics-49486371 [accessed 28 August 2019].
} 
These activities are the things that oil the machinery of social life. They are like 'investments' of time, expertise, good will and energy that 'pay dividends' in terms of social cohesion, a sense of belonging, healthy democracy, less isolation and loneliness. Research suggests religious groups are exceptionally good at mobilising social capital in the shape of volunteers, physical resources such as buildings and local networks. As a result, some people refer to 'religious' or 'spiritual' capital to describe the additional 'premium' that faith groups bring to building up strong and resilient networks and providing routes through which people can become active citizens (Baker, 2012). These - religious values and concrete practices -- form the foundations of a functioning civil society (Dinham, 2012).

An illustration of this combination of physical resources and religious values can be found in a remarkable book, After the Fire: Finding words for Grenfell (Everett, 2018). In the early hours of Wednesday $14^{\text {th }}$ June 2017, fire engulfed Grenfell Tower in London, resulting in 72 deaths and many more being made homeless. Alan Everett, vicar of the nearby St Clement and St James churches, and the book's author, describes how immediately after the terrible fire religious groups of all kinds took the lead. Everett describes the immediate aftermath, of how religious buildings - churches, temples, mosques including the ClementJames centre, a charity run by the local parish - became makeshift evacuation centres; and they turned into bases for relief work, to collect and distribute food, clothing and above all support to local survivors, families and emergency services. As time went on, these same religious centres became the venues of often acrimonious meetings between residents and the local authority. 
Everett also writes, however, of how alongside the immediate material needs, groups like churches found themselves important sources of emotional and spiritual support. In the weeks and months after Grenfell, it becomes more apparent that theological reserves and resources began to play a decisive role in shaping and sustaining the local churches' ministry. His experience of years of ministry and an immersion in a theology of resilience gives him sufficient hope to keep going. He articulates a theology of waiting and mourning, a kind of 'Holy Saturday' - the space between Good Friday and Easter Day, between Cross and Resurrection:

We cannot rush into healing. There are no short cuts. We must give ourselves space to process what we have experienced and we must allow the grace of God to do its work in its own time. Only then can we take the next step, in the hope that God will accompany us and guide us forward. (2018, p. 129)

It is clear that all the churches and other faith groups in Notting Dale, Notting Hill and North Kensington often felt overwhelmed, engulfed, by the waves of all the expectations that were heaped upon them. They felt fragile and were grieving themselves. It was costly for them. But they endured, as Alan Everett says:

Our acts of compassion may feel insignificant, and we are all too often aware that we are not the people we wish to be. But our small offerings of love are part of a larger movement, as over time, in the company of those with whom we live and work, we are taken up into the life of God. $(2018$, p. 124) 


\section{Social Capital and Christian Calling}

The two concepts of 'the common good' and 'social capital' both relate to the nature and meaning of our life together (in church and society); how that is conceived and practised, and how we understand 'public' and the nature of our participation in society. Together they resonate powerfully with a prayer that features in many Christian liturgies, in which worshippers ask God to 'build up our common life'. Could this motif serve, at this particular time, as a focus for our public theology? Can it embody the ways in which Christians and others of faith, who believe themselves to be called to a distinctive vocation to society, as citizens of the world and disciples or followers of Jesus, might contribute in deed and word to build up our common life?

It is important to ask what it might take for the churches to attend to the task of 'building up its own common life' in order to equip its members and leaders carry out these vital tasks of constructive citizenship. This relates to what Stephen Lowe and I identified as a critical dimension of public theology, namely 'the processes of guidance or formation that equip Christians ... to exercise faithful witness in relation to the secular world' (Graham and Lowe, 2009, pp. 4-5), or how ordinary people of faith exercise their commitments in public: at work, as volunteers, in politics. This takes us into the territory of the role of the laity in the life of the Church, and how the 'gathered' and institutional church feeds and nurtures the life and work of the 'scattered' or 'dispersed' church out in the wider public domain (Archbishops' Council, 2016). Do the churches give enough support to those in public service, decision-making, front-line services; to connect what they are doing with their faith? Do churches talk enough about how faith informs lives from Monday to Saturday, as 
well as Sunday; and do we pay sufficient attention to our responsibilities not just as church members but as citizens, consumers and voters? Do local churches afford full value to those who serve their wider communities? What, we might ask, is the relationship between the realm of 'discipleship' and that of 'citizenship' (Graham and Lowe, 2009; Brown, Pattison and Smith, 2012, p. 187)?

If we hold to a strong doctrine of the church's ministry and mission in the world, then there should be no division. But unfortunately, the old dichotomies of public and private, church and world, sacred and secular, often conspire to keep them apart. Yet if theology is merely the internal discourse of the Church, framed in language understandable only to experts or academicians, it will never connect with lived experience and will cease to be relevant. The significance of a discipline like public theology is that it regards itself as less concerned with defending the interests of specific faith-communities than with contributing -- critically and constructively - to the processes of common deliberation and action. At the heart of this undertaking lies a simple, but profound (and, some would say, sacred) question: 'Who is my neighbour?' (Luke 10; see also Graham, 2017, p. 150) 


\section{References}

Ahern, K. Clark, M. Heyer, K. and Johnston, L., eds., 2016. Public Theology and the Global Common Good. New York: Orbis.

Archbishops' Council Lay Leadership Task Group, 2016. Setting God's People Free, London: Church House Publishing.

Asad, T., 2003. Formations of the Secular: Christianity, Islam, Modernity. Stanford, CA: Stanford University Press.

Baker, C. R., 2012. Spiritual Capital and Economies of Grace: Redefining the Relationship between Religion and the Welfare State. Social Policy and Society, pp. 565-576.

Baker, C. R. and Beaumont, J., eds., 2010. Postsecular Cities: Space, Theory and Practice. London: Continuum.

Bedford-Strohm, H., 2007. Nurturing Reason: the public role of religion in the liberal state. Ned Geref Teologiese Tydskrif, 48(1-2), pp. 25-41.

Bishops' Conference of England and Wales, 2010. Choosing the Common Good, Stoke-onTrent: Alive Publishing.

Bonhoeffer, D., 1971. Ethics. London: SCM Press.

Breitenberg, H. J., 2010. What is Public Theology? In: Public Theology for a Global Society. Grand Rapids, Michigan: Wm B. Eerdmans, pp. 3-17.

Brown, M., Pattison, S. and Smith, G., 2012. The Possibility of Citizen Theology: Public Theology after Christendom and the Enlightenment. International Journal of Public Theology, 6(2), pp. 183-204.

Bruce, S., 2002. God is Dead: Secularization in the West. Oxford: Blackwell. 
Bullivant, S., 2017. The "No Religion" Population of Britain, London: Benedict XVI Centre for Religion and Society, St. Mary's University Twickenham .

ComRes, 2013. The Spirit of Things Unseen Spirituality Survey, London: Theos.

Cowan, D. E., 2010. Sacred Space: the Quest for Transcendence in Science Fiction Film and Television. Waco, TX: Baylor University Press.

de Gruchy, J., 2007. Public Theology as Christian witness: exploring the genre. International Journal of Public Theology, 1.1, pp. 26-41.

Dinham, A., 2012. Faith and Social Capital After the Debt Crisis. London: Palgrave Macmillan. Dinham, A. and Francis, M., eds., 2015. Religious Literacy in Policy and Practice. Bristol: Policy Press.

Dinham, A., Furbey, R. and Lowndes, V., eds. 2009. Faith in the Public Realm: Controversies, Policies and Practices. Bristol: Policy Press.

Everett, A., 2018. After the Fire: Finding words for Grenfell. London: Canterbury Press. Fuller, R., 2001. Spiritual but not Religious. Oxford: Oxford University Press.

Graham, E., 2013. Between a Rock and a Hard Place: Public Theology in a Post-Secular Age. London: SCM Press.

Graham, E., 2017. Apologetics without Apology: speaking of God in a world troubled by religion. Eugene, OR: Cascade.

Graham, E. and Lowe, S., 2009. What Makes a Good City? Public Theology and the Urban Church. London: Darton, Longman and Todd.

Habermas, J., 1989. The Public Sphere (first published 1964). In: J. Habermas, ed. Jürgen Habermas on Society and Politics: A Reader. Boston: Beacon Press, pp. 231-236.

Harris, S., 2005. The End of Faith: Religion, Terror, and the Future of Reason. London: Free Press. 
Hjelm, T., ed., 2015. Is God Back? Considering the New Visibility of Religion. London:

Bloomsbury.

Hogue, M., 2010. After the Secular: Toward a Pragmatic Public Theology. Journal of the American Academy of Religion, 78(2), pp. 346-374.

Hollenbach, D., 2006. The Common Good and Christian Ethics. Cambridge: Cambridge University Press.

Kaufmann, E. Goujon, A. and Skirbekk, V., 2012. The End of Secularization in Europe? A Socio-Demographic Perspective. Sociology of Religion, 73(1), pp. 69-91.

Kettell, S., 2015. Illiberal Secularism? Pro-faith discourse in the United Kingdom. In: T. Hjelm, ed. Is God Back? Reconsidering the new visibility of religion. London: Bloomsbury, pp. 65-76. Kim, S., 2011. Theology in the Public Sphere: Public Theology as a Catalyst for Open Debate. London: SCM Press.

Lloyd, G., 1984. The Man of Reason: 'Male' and 'Female in Western Philosophy. London: Methuen.

Lynch, G., 2007. The New Spiriituality: An Introduction to Progressive Belief in the Twentyfirst Century. London: I.B. Tauris.

Maddox, M., 2007. Religion, Secularism and the Promise of Public Theology. International Journal of Public Theology, 1(1), pp. 82-100.

National Centre for Social Research, 2019. British Social Attitudes. 36th edition. London: NatCen Social Research.

Pearson, C., 2007. The Quest for a Global Public Theology. International Journal of Public Theology, 1(2), pp. 151-172.

Pew Forum on Religion \& Public Life, 2012. The Global Religious Landscape: A Report on the Size and Distribution of the World's Population, Washington, DC: Pew Research Center. 
Pew Forum on Religion in Public Life, 2010. Religion among the Millennials, Washington, DC: Pew Research Center.

Putnam, R., 2000. Bowling Alone. New York: Simon \& Schuster.

Sagovsky, N. and McGrail, P. eds., 2015. Together for the Common Good: towards a national conversation. London: SCM Press.

Smit, D., 2007a. What does 'public' mean? Questions with a view to public theology. In: L. Hansen, ed. Christian in Public: Aims, Methodologies and Issues in Public Theology.

Stellenbosch: Sun Press, pp. 11-46.

Smit, D., 2007b. Notions of the Public and Doing Theology. International Journal of Public Theology, 1(3-4), pp. 431-454.

Spencer, N., 2017. Doing Good: a Future for Christianity in the 21st Century. London: Theos. Stackhouse, M., 2006. Public Theology and Ethical Judgement. Theology Today, 54(2), pp. 165-191.

Stackhouse, M.L., 2007a. God and Globalization, Volume 4: Globalization and Grace. New York: Continuum.

Stackhouse, M. L., 2007b. Reflections on How and Why We Go Public. International Journal of Public Theology, 1(3-4), pp. 421-430.

Stoddart, E., 2011. Theological perspectives on a surveillance society: watching and being watched. Farnham: Ashgate .

Strenski, I., 2010. Why Politics Can't Be Freed From Religion. Oxford: Wiley-Blackwell. Sweeney, J., 2008. Revising Secularization Theory. In: G. Ward and M. Hoelzl, eds. The New Visibility of Religion. London: Continuum, pp. 15-29.

Tanner, K., 1996. Public Theology and the Character of Public Debate. Annual of the Society of Christian Ethics, 16(1), pp. 79-102. 
Tippett, K., 2004. Interview with Max Stackhouse. [Online]

https://soundcloud.com/onbeing/unedited-max-stackhouse-with-krista-tippett. [Accessed 23 September 2019].

Tracy, D., 1981. The Analogical Imagination: Christian Theology and the Culture of Pluralism. London: SCM Press.

Tracy, D., 1984. The Role of Theology in Public Life: Some Reflections. Word \& World, 4(3), pp. 230-239.

White, G., 2006. Talking about Spirituality in Health Care Practice. London: Jessica Kingsley. Woodhead, L., 2014. What People really believe about God, Religion and Authority. Modern Believing, 55(1), pp. 49-58.

Woodhead, L. and Catto, R. eds., 2012. Religion and Change in Modern Britain. London: Routledge.

Zsolnai, L. and Flanagan, B., eds., 2019. The Routledge International Handbook of Spirituality in Society and the Professions. London: Routledge.

Elaine Graham is Grosvenor Research Professor of Practical Theology at the University of Chester and President of Modern Church. 